\title{
Convenience Solution to the Time-poor Customer: The Emerging Trend in Marketing
}

\section{Mr. Pramod Kumar Nayak}

Effulgence

Vol. 11 No. 1

January - June, 2013

Rukmini Devi Institute of Advanced Studies

E-mail : effulgence@rdias.ac.in, Website : www.rdias.ac.in http://effulgence.rdias.ac.in/user/default.aspX

\begin{abstract}
A bstract
O ne of themost scarcething in the present ageisTimeand everyoneistrying to maxi mize their utilization of timeand find timeto $r$ lax by channelizing the qual ity ti metowards their work. Thispaper aims at identifying and deliberating the major issues concerning the needs in front of timepoor consumers. The issues like convenience in shopping, food consumption and maintaining a comfort L ife styleareaddressed. In today's world most of the consumersfeel that it is difficult to managetheir daily and day to day obligationsand find timeto relax. Theattitudeto ti methat many now adopt is onethat focuses on leisure time maximization. The big opportunity for the marketers isto find out the solutions that facilitate additional timeto do thethings that are deemed most important is highly valued. The significance of different conveniencealigned trend across different segments of needs of the timepoor consumers has been understood and accordingly possiblesolutionssuggested in thispaper.
\end{abstract}

https://dx.doi.org/10.33601/effulgence.rdias/v11/i1/2013/50-55

Key W ords: TimePoor Consumer, 0 bli gations, Dilemma, Convenience, 0 pportunity

\section{INTRODUCTION}

0 ne thing is common for all human being is; the time is same 24hrs available for everyone. In the era of fast moving life, the demand for the leisure time is increasing. However, the time is the scarce entity and everyone is bothered about time saving. Every activity is so meticulously planned and accomplished, so that at least some time can be saved and can be utilized for some other task somewhere else. There comes the word 'Convenience'. A ccording to Macmillan Dictionary the definition of convenience is "a condition that makes it easier to do something and helps you to avoid wasting time or effort". Now everyone need convenient solution for all the need he/ she posses. The work accomplished in a traditional way may not save time, but the time saving way of doing work is fruitful. To meet the demand of the hour to accomplish day to day task, the convenient solution is bundled with the product or service. The time required for procurement and consumption of product is reduced by providing convenience solution to the customer at the right time and right place. Providing convenience to consumer is now the biggest challenge and also opportunity for the business organizations. The customer satisfaction is associated with timely and easily available of service/ product. For facilitating the leisure time for the consumer, the business barons are breaking their heads, how they can provide convenience to the consumer? That is a big question.

There is a seismic shift in the sphere of customer service; the shift is towards providing convenience. If we look at the development of the consumer durable goods e.g. Microwave, Washing machine, J uicer-M ixer-G rinder; one thing comes to our mind that these products are meant for providing convenience to the user. The invention and innovation basically aims towards the convenience. The on-line reservation, on-line banking services also aims at the convenience to the consumer. So how a better convenience can be provided and also 
for that a substantial amount can be charged from the consumer which will in turn generate ROI; is the prime focus of the business nowadays. With a population of more than 1.2 billion, India is one of the largest consumer markets in the world as per the KPMG International Summit Report 2009.

\section{OBJECTIVES AND METHODOLOGY}

The major objective of this paper is to:

- Identify and understand the consumer characteristics in terms of demography and attitude that influence the customer for convenience solutions to cater their needs.

- Find out the factors affecting the lifestyle in terms of time scarcity of working class.

- $\quad \mathrm{H}$ elp the marketers to understand consumer needs in context of convenience solution based products.

- Find out the opportunities for the marketers in the area of providing convenient solution to the customer.

- To analyse the emerging marketing trends in the context of providing convenience solution to the timepoor consumer.

This is a kind of review paper, hence the methodology used for this study is exploratory in nature as most of the secondary data has been used by referring different research studies and analysis has been done based on the review of the literature of those papers. The findings of the study have been given in the form of analytical review.

\section{LITERATURE REVIEW}

For this study various research papers have been reviewed. O ne important report by Datamonitor in August 2009 which emphasizes on convenience and describes "There are at least two broad dimensions of convenience. The first dimension concerns the type of convenience. Components of this dimension include saving time, physical energy, and/or mental energy either less time spent in the consumption process overall (active time), or availability at a convenient time, i.e. not having to wait (passive time). The second dimension concerns the timing of convenience, i.e. the stage of the consumption process at which convenience is obtained. Researchers must consider convenience needs at all stages in the process and should try to determine the relative weights that consumers attach to time and energy use in acquisition, consumption and disposal".

The D atamonitor consumer survey in A ug 2009 has also established the fact that less than half of consumers across 17 countries are satisfied with their work-life balance. This reflects and emphasizes a lifestyle imbalance that characterizes many contemporary lifestyles. The various types of commitments and different demands from work and from personal/ family life have contributed to the feeling of timedeprivation. Therefore, most of the people are looking for speed and convenience and anything that allows them to feel more in control of time. The consumers are in search of convenience solution. If we take into account of convenience in food consumption, the role of convenience as a factor that influences the food consumption process has been discussed by many authors and a common finding of the empirical studies is that today's consumers demand higher levels of convenience in their foods. This trend is manifested in consumer's food preferences not only in U.S.A. (Senauer, 2001) and W estern Europe (M ahon et al., 2005) but also in developing countries like India where consumption shifts away from sources of calories towards manufactured food products(Gehlhar and Regmi, 2003).

Even though traditionally convenience has been examined in the context of strategies used by the consumer to reduce time pressures but time is not the only dimension involved. Darian and Cohen (1995) proposed two dimensions of convenience. The first one concerns the type of convenience, which can be saving time, physical energy and/ or mental energy. The second dimension refers to the stage of the process that convenience is obtained.

Realizing that classifying wife's work status into working/non working did not help in explaining differences in consumption; researchers began to use other classification schemes. Variables like fulltime/ part-time/ no paid job and high occupational status/low occupational status/non-working wife (Schaninger and A llen, 1981) belong to these efforts. 
"Thinking in terms of time and attention will quickly start to change the way you think about products and services, customer behavior, even business models. This is the great frontier for innovation for the next decade. Companies that master time and attention innovation will find lots of market traction. Those that don't will find themselves standing outside the attention ecosystems, desperately screaming to be heard while opportunities and profits slip away." (Adrian C. Ott, 2011).

\section{C onvenience and $\mathrm{C}$ ustomer $\mathrm{H}$ abits}

Today's consumers are seeking solutions that allow them to maximize their free time and disposable income, and spend more time doing the things they value. The convenience trend is driven by this desire to create more leisure time. In 2009, Datamonitor survey found that $44 \%$ of citizens across 15 countries feel that it is difficult to manage their daily obligations and find time to relax. A nother study discovered that $70 \%$ of A mericans aged 16 years or older feel that they do not have the time to do all the things they need to do. In addition, $50 \%$ of A mericans believe the lack of time is a bigger problem than money. In India also similar type of trend observed. Due to many factors like; changing lifestyles (urban life in particular), nuclear family system, eating $\&$ drinking habits, lighter meals for health conscious, etc. consumers are spending less time planning, procuring, consuming and disposing off the products. This trend is having a dramatic influence on Consumer behaviour in the context of procurement $\&$ consumption.

Convenience is multi-faceted and will continue to evolve and converge with other trends to meet the needs and demands of society. Convenience means more than easyto-get, easy-to-consume, easy-to-dispose of products. Consumers also want convenient products with additional attributes, such as products are useful, ethical, and comforting. The increased use of appliances has been particularly influential. Microwave ovens, for example, save preparation and cooking time. Freezers make food available for later consumption, food processors shorten preparation time, and dishwashers speed clean up (Buckley 2007).

Effulgence, Vol. 11, N o. 1, January - June 2013

\section{FACTORS COMPELLING CUSTOMERS TOWARDS CON VEN IEN CE}

$V$ arious studies show that there are many factors which are responsible for the changing habits and inclination towards convenience products/ services such as:

\section{Sociological Changes}

In today's context joint families are being converted into the nuclear families because of the changing culture. There is huge rise in number of working women, increasing awareness and changing preferences which are attracting many marketers in the sector of food and beverages. The use of high-end convenience products by the customers al so shows the status in the society.

\section{Time pressure}

Time pressure at the workplaces has affected the worklife balance of the employees and there is growing desire among the employees to maximize their leisure time. In this regards they are in search of technology which can save their time and that time can be utilized for other professional activities. This rising stress levels among the employees is also the factor which makes them to search for convenient products/services.

\section{Lack of motivation}

After working for long hours when an employee comes from the office he/ she may feel lack of energy which will not motivate him to cook meals from scratch and hence will search for options that can provide them convenience in terms of desired and ready-made foods. $\mathrm{He}$ / she may also not in a position to go from one shop to another for shopping, so he/ she needs convenience store location wise and also assortment wise.

\section{Lack of knowledge}

In case of Meal preparation, today we find that young couples are not having knowledge to prepare foods and are not in a position to prepare the meal of their choice, this leads them to find the places where they can get the food of their likings. Low confidence in cooking from scratch is also one factor which limits to cook food at their own. This leads to search for convenience. 


\section{Socioeconomic changes}

The transition of India's population across income classes mainly from lower to higher classes is also a factor which is responsible for changing buying habits among the customers. Rise in household consumption level, the growing young population and migration of people from rural to urban cities (increasing urbanization) are also other economic factors which are affecting the buying and consumption habits of the people.

In addition to all these other factors like time scarcity, meal fragmentation, speed shopping and the erosion of skills for household works is stimulating the demand for more convenient options. Working longer hours and lack of household work skills increase the attractiveness of convenience products.

\section{Time scarcity}

Many consumers are feeling overwhelmed by their lifestyle obligations. Timepressured consumers express strong preferences for quick, efficiency-driven products that allow them to feel more in control of their time. This consumer group will multi-task in order to compress more activities into less time, leading to wide behavioural implications. For instance, time scarcity is a common reason for consumers failing to maintain a healthy lifestyle.

\section{SOLUTIONS FOR CONVENIENCE TO CUSTOMER AS BUSINESS OPPORTUNITY: AN AN ALYSIS}

By keeping in all the above factors it can be inferred that convenience product/services sector has emerged as a potential area for most of the marketers in the field of convenience products/services. If we take the food and beverages product alone, the current market size in the context of food consumption is 198 billion USD and expected to grow at a rate of $5.32 \%$ and will reach 230 billion USD by 2013 (ASSOCHAM-KPMG Report2009). There will be major chunk of population depending upon the convenience food due to various factors discussed above. Lifestyle trends that have great impact upon consumer purchasing decisions are becoming very important in today's context. Consumers are becoming increasingly demanding especially in context of food items but don't have time to prepare them, hence seeking solutions that can provide convenience in addition to fulfilling their need.

'O n-the-go' lifestyles have emerged as a result of several factors. Longer working hours, longer commuting times, and a wider range of leisure activities have all contributed to the notion of 'time-poor' consumers. So there are ample number of opportunities lying in the following areas for the marketers who are operating in this sector of food and beverages. These can be: Readyto-eat Food production, Packaging and Distribution.

Packaging is another emerging area for the marketers which are a linking sector for the food chains. Convenience food packaging has been a major feature of packaging markets in recent times due to rising sales of convenience foods and developments. Packaging technology has developed to the extent that the readymeal, pack and take, take-away offer has improved significantly. Attracting a broader and also wealthier customer base than previously is possible, as consumers are prepared to pay a premium for quality, preprepared meals.

Consumer health concerns are an increasing influence in many end-use markets for packaging. Examples include:

- Rising sales of bottled water, fruit juice and milk drink markets in many countries, to the detriment of spirits and, in some countries, carbonated soft drinks;

- Increasing demand for packaged fresh food products.

Packaging is also a major cost component in the majority of consumable products. T aking an example, 48 cents out of every dollar (48\%) of Coke's product cost is from packaging. Of the total market, $60 \%$ lies in the areas of primary containers and flexible packaging-the containers and wrappers that give immediate protection to the packaged product.

Convenience stores continue to make headway and grow strongly, located in airports, train station and city centres. In emerging markets, super and hypermarkets are expanding rapidly, boosting overall consumption and also taking market share from the traditional local 
(open) market, where most of the produce is not individually packed. Various issues will affect future retail trends, including consolidation, technology, service, quality and trust, lifestyle and emotions. O n-line retailing, with goods, being delivered through the post or via retailers own fleets of delivery vans, is expanding strongly. Development tailored to the needs of on-line retailing will be necessary.

Convenience has a very important role in Marketing Mix also. The more traditional approach to marketing mainly emphasizes product mix in differentiating the retail stores from its competitors. Today, convenience is taken the prominent place in the marketing mix. Convenience is more important in marketing today due to change in the family life style, family size and due to trend in the both spouses working for bread earning. The opportunity for the marketer is 'C reating Convenience'. Basically we interpret marketing convenience as a location convenient and close to home or work, but today shoppers want other way to save time. They want the product and service to be provided to them in a convenient manner. For example Home delivery system, service at a call at door step etc. So the service industry is gearing up for providing better home service. Customers are also willing to pay more for convenience. Imagination and understanding of the customers' needs will definitely suggest other approaches to creating convenience and thereby improving the competitive position in the market.

The No-Waiting style of service is also a better opportunity for the business in service industry. C ustomers are interested in convenience and they do not want to wait. They likely have selected the store because there is less waiting time. The marketing strategy in this regard must have the plan for adequate staffing, especially during peak hours. A nticipate the customer arrival and be prepared for the service to be provided to the customer without waiting period.

Consider the case of a convenience store, what made the convenience store convenient? The store is located near to the customers' work or living place, it is easy to drive or walk to. But another aspect of convenience is the store carried $80 \%$ of the items that supermarket carryaddressing most of your needs at one stop. The marketer must emphasize both the point in regards to convenience store.

For efficient shopping by the customer, convenience has the impact upon the store selection and in-store behaviours. Grocery store preferences are heavily influenced by the convenience of the location; consumers want grocery stores to offer convenience in the form of flexible (long) opening hours and convenient proximity to their homes. Consumers are adopting a more flexible approach to shopping where larger shops are combined with more frequent 'top-ups' the convenience offered by a plethora of convenience stores and evolving formats in larger grocery stores means that consumers are increasingly disposed to top up shopping. A nother trend is Speed Shopping in this consumers, despite being attracted to new experiences, often simply engage in 'auto pilot purchasing' which leads to more habitual buying. A reluctance to spend too long shopping for groceries could mean that it is becoming more difficult for new products to receive attention from the majority of consumers. The modern trend now evolves is 0 nline Grocery Shopping and in this format more consumers are embracing the internet for the purpose of convenient shopping. online grocery retail has established a strong foothold but remains an area with room for development, not least because consumers are still only seeing it as a relatively fringe offering

\section{CONCLUSION}

In the concluding part it can be said that there are many factors driving the change which includes changing lifestyle, habits, and increasing urbanization, young population, changing working culture, nuclear families and many more. Providing easiness in service through innovative solution in the $24 \times 7$ working environment of the customer is a challenging task but the business opportunity lies there. 0 ne of the biggest problems in front of the customer is the managing the time and customer may be cash-rich but is time-poor. To provide the convenient solution to fulfill the needs of the timepoor consumer is the opportunity in front of the $M$ arketer and simultaneously it is a challenge also. The technology is also now days helping the marketer to innovate some new format of convenience solution 
through E-Commerce, Virtual Marketing, O nline$M$ arketing etc. The e-commerce era is coming up and growing at a faster space. The online store with click and select provision for the customer is now a trend in business. The virtual merchandising format is also a new emerging concept for displaying the product in a virtual platform like internet; kiosks, large display screen etc and customer select the product and communicate to the retailer to supply the product at the door step of the customer. Similarly when the customer wants to select apparel, he/ she can select it through internet from a large variety of choices virtually displayed in internet portal and place an order for the selected apparel to the retailer. By providing the effective solution in the context of convenience, the marketer can gain a competitive advantage and providing the effective solution to time-poor customer, which is one of the emerging trends in $\mathrm{M}$ arketing.

\section{REFERENCES}

1. Assocham KPMG International Summit Report (2009)

2. A drian C. Ott (2011). "The Invisible $\mathrm{H}$ and of Time: How Attention Scarcity Creates Innovation O pportunity", I vey Business Journal, March/A pril 2011, accessed through www.iveybusinessjournal.com/ on 24 September 2012.

3. Businessworld M arketing W hitebook, (2010-2011)

4. Becker, G. S. (1965). "A theory of the allocation of time". The Economic J ournal, Page 75, 493-517.

5. Buckley, M., Cowan, C., McCarthy, M. and 0 . Sullivan, C. (2005). "The convenience consumer and food-related lifestyles in Great Britain". Journal of Food Products M arketing, 11 (3), page 3-25.

6. Darian, J. C . and Cohen, J. (1995). "Segmenting by consumer time shortage. Journal of Consumer M arketing", 12 (1), 32-44.

7. Feldman, L. P. and Hornik, J. (1981). "The use of time: A n integrated conceptual model.Journal of Consumer Research", 7 (4), 407-419.

8. International Markets Bureau, Market A nalysis Report, ( June 2010)

9. Schaninger, C. M. and Allen, C. T. (1981). "W ife's occupational status as consumer behaviour constructs. The Journal of C onsumer Research", 8 (2), 189-196.

10. Www.mckinseyquarterly.com/Food_A griculture/ Packaged_Foods/Indias_sleeping_giant_Food_870 accessed on 29 F eb 2012

11. www.business-standard.com/ india/ news/kitchanging-eating-habits-in-india/ 380248/ 29 Feb 2012

12. www.datamonitor.com/ store/ R eport-2009 accessed on $20 \mathrm{M}$ ay 2012.

13. $W$ w w . igd.com/ index. asp id $=1 \&$ fid $=1 \&$ sid $=26$ $\&$ cid $=91$ accessed on 21 M ay 2012.

14. www.findarticle.com/ p/articles/ mism3374 accessed on 21 M ay 2012.

15. www.marketingprofs.com/2/ saucier.asp accessed on 21 M ay 2012. 